\title{
BCR-signaling-induced cell death demonstrates dependency on multiple BH3-only proteins in a murine model of B-cell lymphoma
}

\author{
MJ Carter ${ }^{1}$, KL Cox ${ }^{1}$, SJ Blakemore ${ }^{1}$, YD Bogdanov ${ }^{1}$, L Happo ${ }^{2}$, CL Scott ${ }^{2}$, A Strasser ${ }^{2}$, GK Packham $^{3}$ and MS Cragg ${ }^{*, 1}$
}

Genetic recombination during B-cell development regularly results in the generation of autoreactive, potentially pathogenic B-cell receptors (BCRs). Consequently, multiple mechanisms link inappropriate BCR specificity to clonal deletion. Similar pathways remain in malignant B cells, offering the potential for targeting BCR signaling. Recently, small molecule inhibitors have realized this potential and, therefore, a deeper understanding of BCR-induced signaling networks in malignant cells is vital. The BH3-only protein Bim has a key role in BCR-induced apoptosis, but it has long been proposed that additional BH3-only proteins also contribute, although conclusive proof has been lacking. Here, we comprehensively characterized the mechanism of BCR-induced apoptosis in $\mathrm{E} \mu$-Myc murine lymphoma cells. We demonstrate the upregulation of Bim, Bik, and Noxa during BCR signaling in vitro and that intrinsic apoptosis has a prominent role in anti-BCR antibody therapy in vivo. Furthermore, lymphomas deficient in these individual BH3-only proteins display significant protection from BCR-induced cell death, whereas combined loss of Noxa and Bim offers enhanced protection in comparison with loss of Bim alone. Some but not all of these effects were reversed upon inhibition of Syk or MEK. These observations indicate that BCR signaling elicits maximal cell death through upregulation of multiple BH3-only proteins; namely Bim, Bik, and Noxa.

Cell Death and Differentiation (2016) 23, 303-312; doi:10.1038/cdd.2015.97; published online 17 July 2015

Functional, signaling competent BCRs deliver critical prosurvival signals, termed tonic signals, which maintain and promote both non-transformed and neoplastic B-cell survival. ${ }^{1-3}$ During B-cell development, iterative recombination of heavy and light chain immunoglobulin (Ig) loci culminates in the generation of a B-cell receptor (BCR) repertoire with diverse antigen-binding potential. ${ }^{1}$ This nonspecific recombination raises the possibility of generating autoreactive, pathological clones. Therefore, during development, mechanisms are in place that trigger deletion of autoreactive B-cell clones after BCR engagement. ${ }^{4-6}$ Deletion appears driven by three distinct mechanisms: low affinity interaction with soluble antigen preferentially invokes either cellular anergy or re-initiation of Ig locus recombination, termed receptor editing. ${ }^{7}$ In contrast, high affinity interactions with membrane-bound auto-antigen predisposes toward programmed cell death. ${ }^{4,6}$

Because BCR ligation via monoclonal antibodies (mAbs) drives apoptosis in normal and neoplastic $B$ cells, the unique BCR expressed by each tumor constitutes an attractive therapeutic target. ${ }^{8-10}$ Accordingly, anti-idiotypic mAbs have proved successful in limited-scale clinical trials. ${ }^{11}$ Although such labor-intensive, patient-specific therapies remain impractical, a deeper understanding of events leading to BCR-induced apoptosis may engender alternative therapies. For example, small molecule inhibitors have begun to realize the potential of targeting pro-survival BCR signaling. ${ }^{12}$ Although responsive to such therapy, malignant cells often also remain sensitive toward BCR-directed $\mathrm{mAb}$ killing. Therefore, combinational inhibition of pro-survival BCR signals alongside pharmacological activation of BCRmediated cell death pathways may prove therapeutically fruitful. However, at present, the precise molecular events that drive BCR-induced apoptosis in B-cell neoplasms remains poorly defined. ${ }^{10}$

In mammalian cells, apoptosis occurs via the extrinsic and intrinsic pathways, culminating in effector caspase activation, degradation of key intracellular components, and ultimately cell death. ${ }^{13}$ Extrinsic pathway activation follows ligation of members of the TNF-R family, such as CD95/Fas, leading to caspase-8 activation. ${ }^{13}$ In contrast, the intrinsic pathway drives caspase- 9 and then effector caspase activation via apoptogenic factors released following mitochondrial outer membrane permeablization $(\mathrm{MOMP}){ }^{14}$ This process is

\footnotetext{
${ }^{1}$ Antibody and Vaccine group, Cancer Sciences Unit, University of Southampton, Faculty of Medicine, Tremona Road, Southampton, SO16 6YD, UK; ${ }^{2}$ The Walter and Eliza Hall Institute of Medical Research, Parkville 3050, Victoria, Australia and ${ }^{3}$ Cancer Sciences Unit, University of Southampton, Faculty of Medicine, Tremona Road, Southampton, SO16 6YD, UK

*Corresponding author: MS Cragg, Antibody and Vaccine Group, Cancer Sciences Unit, General Hospital, Southampton University Faculty of Medicine, Southampton, S016 6YD, UK. Tel: +44 (0) 23 81208452; Fax: +44 (0) 23 80704061; E-mail: msc@ soton.ac.uk

Abbreviations: BCR, B-cell receptor; Ig, immunoglobulin; mAbs, monoclonal antibodies; TNF-R, tumor necrosis factor receptor; MOMP, mitochondrial outer membrane permeablization; Fc $\gamma \mathrm{R}, \mathrm{Fc} \gamma$ receptor; Fc $\gamma \mathrm{R} \gamma$, Fc $\gamma$ receptor common $\gamma$ chain; TIL, tumor-infiltrating lymphocyte; Btk, Bruton's tyrosine kinase; GAPDH, Glyceraldehyde phosphate dehydrogenase; mAb, Monoclonal antibody; pAb, Polyclonal antibody; PARP, poly (ADP-ribose) polymerase; PI3K, phosphoinositide-3 kinase; ERK, extracellular regulated kinase; Syk, spleen tyrosine kinase; MEK, MAPK/ERK kinase kinase; IgM, immunoglobulin M, $\Delta \Psi \mathrm{m}$, change in mitochondrial membrane potential; E2-F, transcription factor family including E2F and DP-like subunits; HIF1 $\alpha$, hypoxia-induced factor-1 $\alpha$; PKC, protein kinase-C; PLC $\gamma 2$, phospholipase-C $\gamma 2$ Received 03.12.14; revised 17.5.15; accepted 11.6.15; Edited by R Sordella; published online 17.7.15
} 
subjected to complex regulation by the $\mathrm{Bcl}-2$ protein family. ${ }^{15}$ It is generally accepted that MOMP is driven through oligomerization of pro-apoptotic Bax-like Bcl-2 family members (Bax, Bak, and possibly Bok) at the outer mitochondrial membrane. ${ }^{16,17}$ In healthy cells, Bax-like proteins are actively repressed by prosurvival $\mathrm{Bcl}-2$ family members $(\mathrm{Bcl}-2, \mathrm{Bcl}-\mathrm{X}$, $\mathrm{Bcl}-\mathrm{w}, \mathrm{Mcl}-1$, and Bfl-1). Following cellular stresses, the proapoptotic BH3-only proteins (Bim, Bid, Puma, Noxa, Bik, Bmf, Hrk, and Bad) de-repress Bax-like proteins, ${ }^{18,19}$ thereby initiating apoptosis. Both intrinsic and extrinsic apoptosis have profound roles in B-cell biology via regulation of cellular homeostasis and tumor suppression. ${ }^{20,21}$ Indeed, mice lacking Bim (or overexpressing Bcl-2) exhibit lymphocyte hyperplasia and antibody-mediated autoimmune pathology. ${ }^{22,23}$ However, more subtle dysregulation of the lymphocyte compartment is also evident upon loss of Puma, Bmf, or Noxa. ${ }^{24-29}$ Furthermore, combined loss of Bim alongside other BH3-only proteins (e.g. Bim and Puma) causes more severe defects than loss of Bim alone. ${ }^{24,30}$ Such observations indicate that Bim represents the major, but not the sole, apoptotic regulator of B-cell homeostasis.

Accordingly, BCR-signaling-induced cell death appears to engage intrinsic apoptosis, ${ }^{8,9,31}$ predominantly via transcriptional upregulation and alternate splicing of Bim. ${ }^{32,33}$ However, because genetic loss of Bim fails to deliver complete resistance toward $\mathrm{BCR}$-induced apoptosis, roles for additional BH3-only proteins are implied. ${ }^{10}$ In this investigation, we characterized the involvement of other $\mathrm{BH} 3$-only proteins and assessed their relative contribution toward BCR-induced cell death. We report that, in addition to Bim, BCR signaling results in the upregulation of both Bik and Noxa, which perform key sensitizing roles in apoptosis. Furthermore, we demonstrate for the first time that concomitant loss of Bim and Noxa, and to a lesser extent $\mathrm{Bim}$ and $\mathrm{Bik}$, generates greater resistance against BCR-induced cell death in B lymphomas than loss of Bim alone.

\section{Results}

Both in vivo and in vitro BCR stimulation induces intrinsic/mitochondrial apoptosis via a Syk/MEK-dependent pathway. Although Bim represents the major driver of BCR-induced cell death in non-transformed B cells, ${ }^{10,32,33}$ loss of Bim does not yield equivalent resistance to that produced by $\mathrm{Bcl}-2$ overexpression, ${ }^{10}$ indicating roles for additional $\mathrm{BH} 3-$ only proteins. To identify these additional drivers and expand these studies to neoplastic B cells, we analyzed the sensitivity of a series of $\mathrm{BH} 3-$ only protein deficient $\mathrm{E} \mu$-Myc lymphomas toward BCR stimulation.

To verify that $\mathrm{E} \mu-\mathrm{Myc}$ lymphomas were sensitive to killing by anti-BCR $m A$ bs through apoptosis, $\operatorname{lgM}^{+} \mathrm{E} \mu-\mathrm{Myc}$ lymphomas were transduced with a FLAG-tagged $\mathrm{hBcl}-2$ construct (Supplementary Figures $1 \mathrm{~A}$ and $\mathrm{B}$ ) and inoculated into $\mathrm{SCID} / \mathrm{NOD} / \mathrm{F}_{\mathrm{C} \gamma \mathrm{R}^{-1-}}$ mice. These mice lack $\mathrm{T}$ and $\mathrm{B}$ cells, have reduced NK activity, and lack the activatory $\mathrm{Fc}_{\mathrm{C}} \mathrm{R}$ required for $\mathrm{mAb}$ deletion through immune-effector cells. ${ }^{34}$ This approach allowed the contribution of apoptosis to the antitumor response following BCR stimulation to be assessed in the absence of other potential effector systems. Mice receiving mock-transduced $\mathrm{E} \mu$-Myc lymphoma cell lines demonstrated significant therapeutic responses toward anti-lgM mAb, increasing median survival from 16 to 25 days in comparison with non-treated animals. However, $\mathrm{Bcl}-2$ overexpression completely abrogated this response (Figure 1a). Interestingly, Bcl-2-transduced lymphomas exhibited a reduced rate of growth in vivo, as previously described. ${ }^{35}$ Such differences may result from enhanced immunogenicity or through Bcl-2mediated constraint of cell-cycle progression. ${ }^{35,36}$ Similarly, in vitro $\mathrm{Bcl}-2$ overexpression conferred almost complete resistance toward $\mathrm{BCR}$ signaling induced cell killing in all E $\mu$-Myc lymphoma cell lines examined, whereas transduction with the empty vector had little effect (Figure 1b). Despite the purported interaction between $\mathrm{Bcl}-2$ and $\mathrm{IP}_{3}$ receptors ${ }^{37} \mathrm{BCR}$ induced $\mathrm{Ca}^{2+}$ flux was not altered in Bcl-2-transduced $\mathrm{E} \mu-\mathrm{Myc}$ lymphoma cell lines (Supplementary Figure 1C). Taken together, these data implicate the intrinsic apoptotic pathway as the key driver of anti-IgM therapy in this system.

Intrinsic/mitochondrial apoptosis drives both caspasedependent and -independent cell death following Bax/Bakdependent MOMP. ${ }^{14,38-40}$ In order to dissect the BCR-induced apoptotic pathway, the effect of the pan-caspase inhibitor qVD-OPH was assessed. Anti-IgM stimulation induced a robust reduction in mitochondrial membrane potential $(\Psi \mathrm{m})$ (Figure 1c). This drop in $\Psi_{\mathrm{m}}\left(\Delta \Psi_{\mathrm{m}}\right)$ was completely abrogated by overexpression of Bcl-2, yet appeared unaffected by qVDOPH pre-treatment. Contrastingly, anti-IgM-induced apoptotic morphology and biochemical markers (e.g. Annexin $\mathrm{V}$ staining) were almost entirely abrogated by either qVD-OPH pretreatment or overexpression of Bcl-2 (Figure 1c).

BCR stimulation induced substantial PARP cleavage and accumulation of cleavage fragments (indicative of activation) of caspases-9, -2, -3 (Figure 1d), -6, and -7 (Supplementary Figure 2). At rest, significant levels of PARP cleavage were evident in untreated $\mathrm{E} \mu-\mathrm{Myc}$ lymphoma cells (Figure 1d), likely attributable to ongoing Myc-driven oncogene-induced cell death. ${ }^{41}$ Considered alongside the finding that $\mathrm{Bcl}-2$ overexpression protects against BCR stimulation-induced cell death and $\Delta \Psi \mathrm{m}$ (Figure $1 \mathrm{~b}$ ), these observations imply that antiIgM antibody-induced cell death induces caspase-independent $\Delta \Psi_{\mathrm{m}}$ prior to the generation of a caspase-driven execution phase, a hallmark of intrinsic/mitochondrial apoptosis.

In order to confirm a requirement for BCR signaling in antiIgM-induced apoptosis, the impact of inhibitors of BCRactivated kinases were examined. BCR stimulation of E $\mu$-Myc lymphoma cell lines induced rapid and robust phosphorylation of Syk, ERK, Akt, JNK, and p38 but had little impact upon c-Myc expression (Figures $2 \mathrm{a}$ and b, Supplementary Figures 3 and 4, and data not shown). Accordingly, the Syk-inhibitor R406 and the MEK1/2 inhibitor PD0325901 significantly reduced BCR-induced ERK phosphorylation (Figures $2 \mathrm{~b}$ and $\mathrm{c}$ ). Furthermore, R406mediated Syk inhibition correlated with the inhibition of Syk autophosphorylation at Tyr ${ }^{525}$, whereas the Src family PTKdependent phosphorylation of $\mathrm{Tyr}^{352}$ remained unaffected. Intriguingly, inhibition of ERK phosphorylation correlated with reduced apoptosis after BCR stimulation (Figure 2d). In contrast, LY294002-mediated PI3K inhibition had little impact (Supplementary Figures $3 \mathrm{~A}$ and $\mathrm{B}$ ). These observations imply that some but not all BCR-inducible kinases are 
a

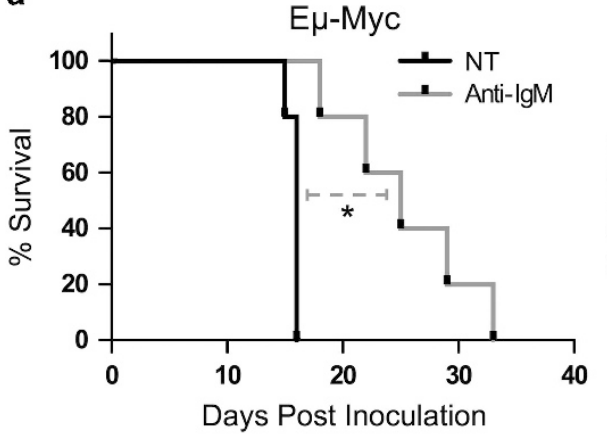

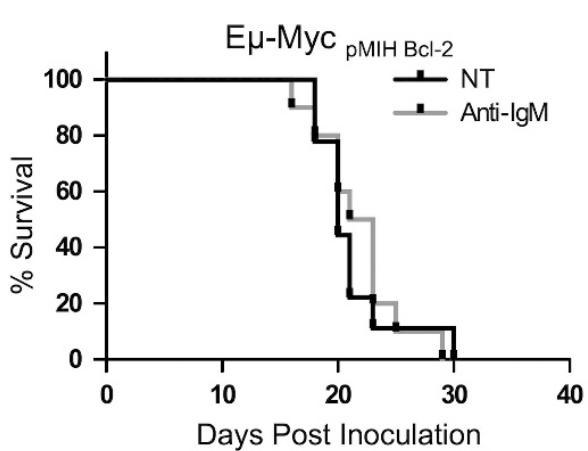

b

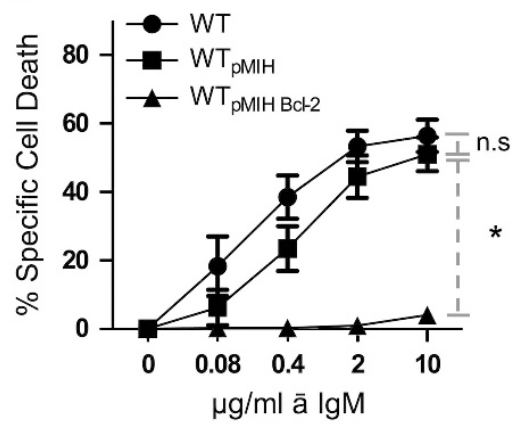

C

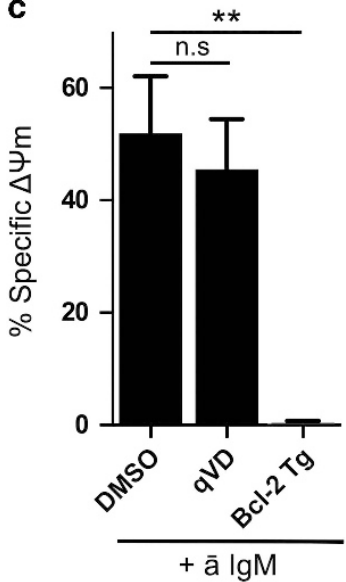

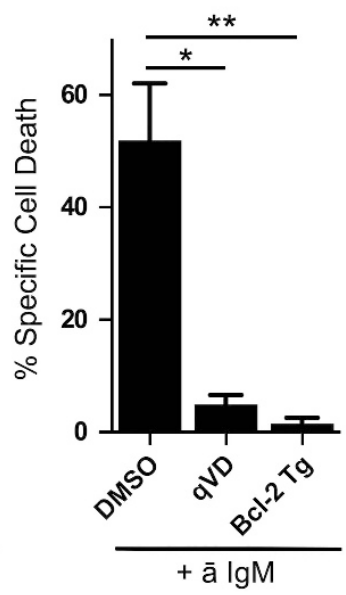

d

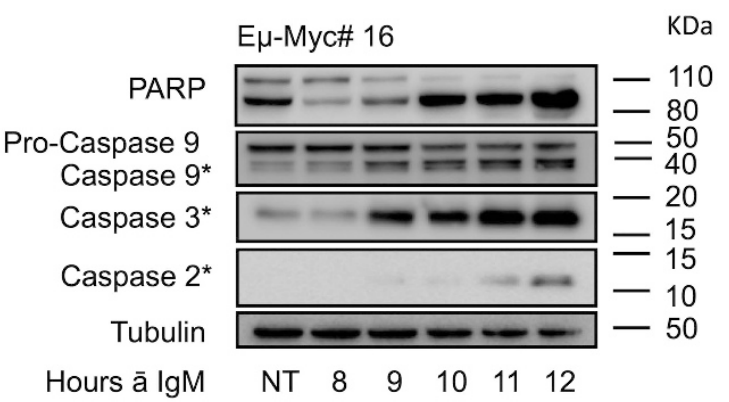

Figure 1 Anti-lgM antibody treatment induces caspase-dependent cell death via the intrinsic apoptotic pathway. Human Bcl-2 overexpressing (pMIH Bcl-2) and empty vector $(\mathrm{pMIH})$ transduced $\mathrm{E} \mu$-Myc lymphoma cell lines were utilized to inoculate SCID/NOD/Fc $\gamma \mathrm{R} \gamma^{-1}$ - mice (a) or for in vitro cell death assays (b). (a) Five mice per group were treated weekly with $125 \mu \mathrm{g}$ anti-IgM Rat IgG2a mAb (Clone: Mc39.12) commencing on day 7 post inoculation for 3 weeks. Data presented represent an average of two independent experiments. ${ }^{*} P<0.05$ by Mantel-Cox statistical analysis. (b) Non-transduced $(n=5)$, empty vector control $(n=4)$, and Bcl-2 transduced $(n=4)$ E $\mu$-Myc lymphoma cell lines were subjected to increasing concentrations of polyclonal (pAb) anti-lgM F(ab) $)_{2}$ for $24 \mathrm{~h}$ and cell viability assessed by Annexin V/PI flow cytometry. ${ }^{*} P<0.05$ by two-way ANOVA statistical analysis. (c) Non-transduced E $\mu$-Myc lymphoma cell lines $(n=4)$ were cultured as in $(\mathbf{b})+/-25 \mu \mathrm{M}$ qVD-OPH and compared with pMIH Bcl-2 transduced E $\mu$-Myc lymphoma cell lines $(n=4)$. Cell lines were subjected to $10 \mu \mathrm{g} / \mathrm{ml} \mathrm{pAb}$ ā IgM F(ab) $)_{2}$ for $24 \mathrm{~h}$ and cell viability was analyzed by staining with DiOC6/PI (left panel) or Annexin V/PI (right panel) followed by flow cytometry. Data are represented as \% specific reduction in $\Psi$ m. ${ }^{*} P<0.05$ by paired Student's $T$-test analysis. (d) Representative blot demonstrating anti-IgM antibody-induced caspase activation and PARP cleavage kinetics. E $\mu$-Myc lymphoma cell lines were cultured as in $\mathbf{b}$ and data are representative of three independent experiments. NT denotes PBS-treated cells harvested after $12 \mathrm{~h} . \mathrm{n}$ denotes the number of different $\mathrm{E} \mu$-Myc lymphoma cell lines used in all experiments. $\mathrm{n} . \mathrm{s}=$ not statistically different. ${ }^{* *} P<0.005$

responsible for anti-IgM antibody-induced apoptosis and highlight a Syk/MEK/ERK-dependent apoptotic mechanism.

Interestingly, the inhibitory effect of PD0325901 upon BCRinduced cell death was not shared between lymphoma cells and non-transformed B cells (Supplementary Figure 5A). Therefore, $\mathrm{E} \mu$-Myc lymphomas appear to exhibit differences in BCR-induced signaling networks in comparison with their nonneoplastic counterparts.

BCR signaling upregulates multiple pro-apoptotic members of the Bcl-2 family. Because the $\mathrm{Bcl}-2$ family represent central regulators of intrinsic apoptosis, ${ }^{18}$ the impact of BCR stimulation upon expression of the Bcl-2 family was assessed by qPCR and western blotting. Of the BH3-only proteins, only Hrk transcripts could not reliably be detected in E $\mu-M y c$ lymphoma cells (data not shown) consistent with previous reports that Hrk is not expressed, or required for apoptosis, in murine lymphoid cells. ${ }^{42}$ Anti-IgM stimulation significantly enhanced Bim, Bik, and Noxa transcript levels in all E $\mu-M y c$ lymphoma cell lines examined (Figure 3a), whereas little variation was evident in other $\mathrm{Bcl}-2$ family members (Supplementary Figure 6B and data not shown). To examine the generality of these effects, the impact of BCR stimulation upon Bim, Bik, and Noxa transcript expression was examined in murine B-lymphocytes and in human lymphoma cell lines (Ramos and Daudi) (Supplementary Figures 7 and 8). All models exhibited dose-dependent anti-lgM-induced cell death and, in the case of Ramos, this was abrogated upon Bcl-2 overexpression (Supplementary Figure 8B). The pattern of BCR-induced Bim, Bik, and Noxa transcriptional upregulation was conserved in all models, albeit with varying magnitude and kinetics. At the protein level, BCR stimulation imparted significant increases in the levels of both Bim $\mathrm{EL}_{\mathrm{L}}$ and $\mathrm{Bim}_{\mathrm{L}}$ isoforms, congruent with decreased $\mathrm{Bcl}-2$ (Figure $3 \mathrm{~b}$ ) and $\mathrm{Mcl}-1$ in $\mathrm{E} \mu-\mathrm{Myc}$ lymphoma cell lines (Supplementary Figure 6C) and normal B-lymphocytes (Supplementary Figure 7), consistent with previous studies. ${ }^{10}$ Presumably, such BCR-induced decreases in $\mathrm{Bcl}-2$ expression were overcome by ectopic expression of the $\mathrm{hBcl}-2 \mathrm{Tg}$, because $\mathrm{pMIH} \mathrm{Bcl-2}$ bearing lymphomas appeared completely 
a

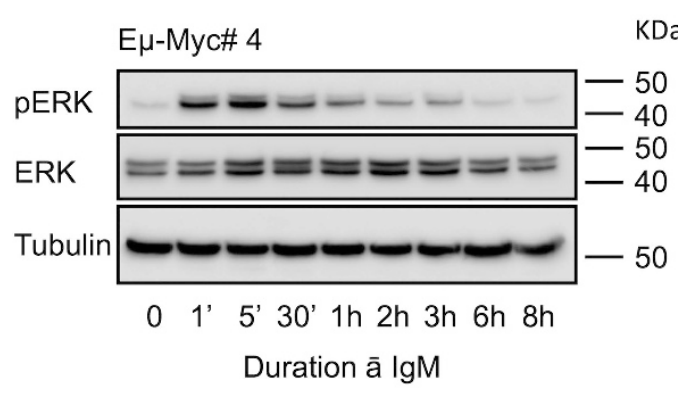

C

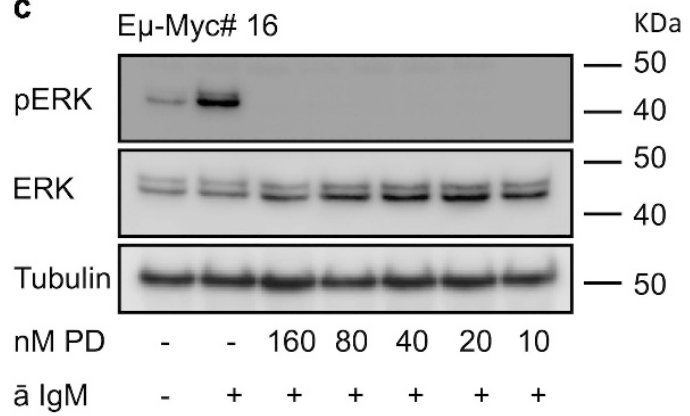

b

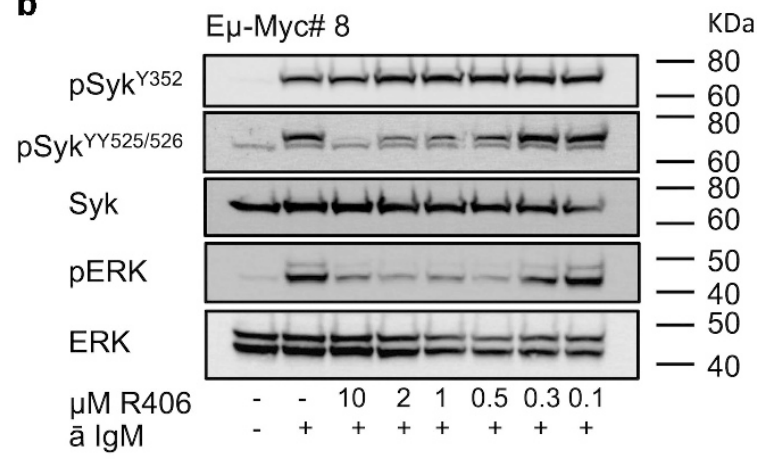

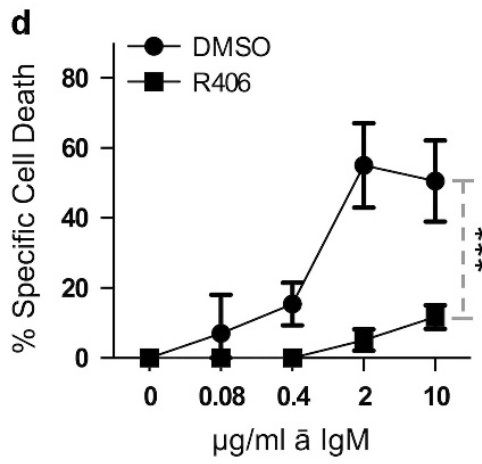

Figure 2 Inhibition of BCR stimulation-inducible kinases diminishes the extent of anti-IgM antibody treatment-induced cell death. Eu-Myc lymphoma cells were stimulated with pAb anti-IgM F $(a b)_{2}$ for the indicated time period, and the phosphorylation status of ERK assessed by western blotting (a). ' denotes minutes and $h$ denotes hours. The impact of Syk or MEK inhibition upon BCR-induced kinase activation was assessed in these lymphoma cells by pre-incubation with the indicated concentrations of R406, PD0325901, or relevant vehicle control for $1 \mathrm{~h}$, followed by anti-lgM F (ab) $)_{2}$ treatment for $3 \mathrm{~min}$ and western blotting $(\mathbf{b}, \mathbf{c})$. The impact of MEK or Syk inhibition upon BCR stimulation-induced cell death was assessed by pre-incubation of E $\mu$-Myc lymphoma cell lines $(n=3)$ with $10 \mathrm{nM}$ PD0325901 or $1 \mu \mathrm{M} R 406$ followed by anti-lgM F(ab) 2 application for $24 \mathrm{~h}(\mathrm{~d})$. Cell viability was assessed by Annexin V/PI staining followed by flow cytometry. $n$ denotes the number of different E $\mu$-Myc lymphoma cell lines used in all experiments. Statistical analyses were performed using two-way ANOVA statistical analysis ${ }^{*} P<0.05,{ }^{* * *} P<0.0005$

resistant to BCR-induced apoptosis both in vitro and in vivo (Figures $1 \mathrm{a}$ and $\mathrm{b}$ ). In contrast, BCR-induced $\mathrm{Bim}_{\mathrm{S}}$ upregulation was largely undetectable. Because suitable antibodies to detect murine Bik and Noxa were unavailable, the impact of anti-IgM stimulation upon Bik, Bim, and Noxa protein levels was assessed in the human Burkitt's lymphoma cell line Ramos. Significant upregulation of Bim, Bik, and Noxa was observed following BCR stimulation in Ramos cells (Supplementary Figure 8C). However, Noxa upregulation at the protein level was evident only at later time points, and did not correlate with increased Noxa transcript levels (Supplementary Figure $8 \mathrm{C}$ and data not shown).

In $E \mu-M y c$ lymphoma cells, increased Bim expression correlated with enhanced co-immunoprecipitation with pro-survival $\mathrm{Bcl}-2$ family members following anti-lgM stimulation, indicative of enhanced pro-survival neutralization (Figure 3c). Consistent with their inhibitory effect upon BCRinduced apoptosis, both R406 and PD0325901 blocked BCR stimulation-induced increases in Bim transcripts, while PD0325901 also blocked increases of Bim protein levels (Figures $3 d$ and e). We were unable to assess the impact of R406 on BCR-induced Bim protein upregulation because R406-treated cells exhibited high levels of death after $24 \mathrm{~h}$. In contrast, neither R406 nor PD0325901 appeared able to fully block Bik or Noxa transcript upregulation, although augmentation of the kinetics of Bik upregulation was apparent (Supplementary Figure 6A). These data implicate Bim as the major driver of BCR-induced killing of lymphoma cells. Accordingly, Bim ${ }^{-1-} \mathrm{E} \mu-\mathrm{Myc}$ lymphoma cell lines exhibited extensive resistance toward BCR-induced cell death (Figure 3f). Interestingly, PD0325901 failed to further enhance resistance of $\mathrm{Bim}^{-1-} \mathrm{E} \mu$-Myc lymphoma cell lines toward BCR-induced apoptosis (Supplementary Figure 5B). Thus, the inhibitory effect of PD0325901 is restricted to inhibition of MEK-dependent Bim upregulation following BCR ligation. However, because the loss of Bim failed to yield resistance equivalent to that produced upon $\mathrm{Bcl}-2$ overexpression, a role for additional BH3-only proteins downstream of MEKindependent BCR signaling was indicated.

Genetic loss of Noxa or Bik renders E $\mu$-Myc lymphoma cell lines partially resistant toward anti-IgM-induced cell death. Because upregulation of Bik and Noxa transcripts were evident following BCR stimulation, the impact of genetic loss of either Bik or Noxa upon BCR-induced apoptosis was assessed. Bik- or Noxa-deficient E $\mu$-Myc lymphomas, described previously, ${ }^{43}$ demonstrated a slight but significant reduction in the extent of cell death induced upon anti-IgM antibody treatment (Figures $4 a$ and b). This resistance was evident at all concentrations of anti-IgM antibody, in all cell lines analyzed, and corresponded to a decreased magnitude of effect in both $\mathrm{Bik}^{-1-}$ and $\mathrm{Noxa}^{-1-} \mathrm{E} \mu$-Myc lymphomas, and an $E_{D} 50$ shift in $\mathrm{Noxa}^{-1-}$ E $\mu-M y c$ lymphomas (Supplementary Figure 9A). 
a

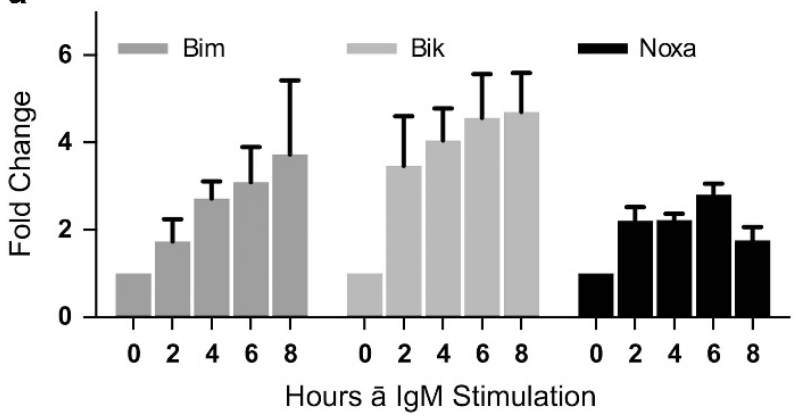

C

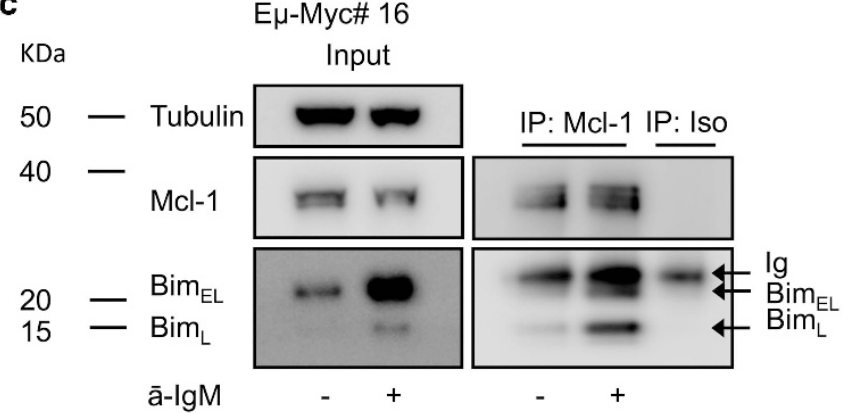

e Ен-Мус\# 16

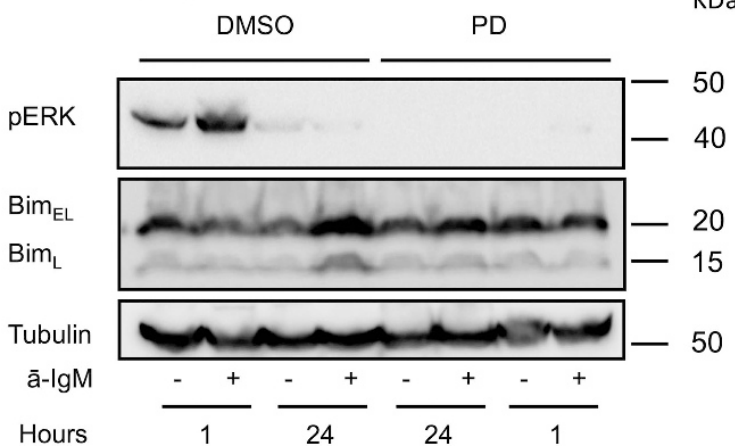

b

Eᄊ-Myc\# 8

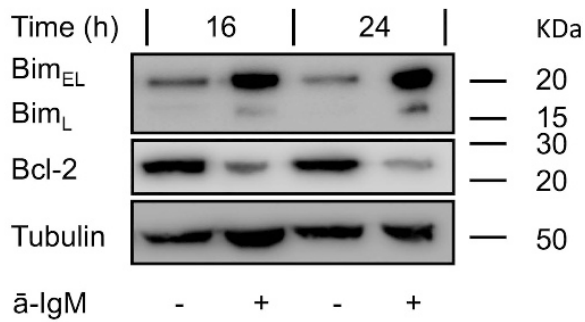

d
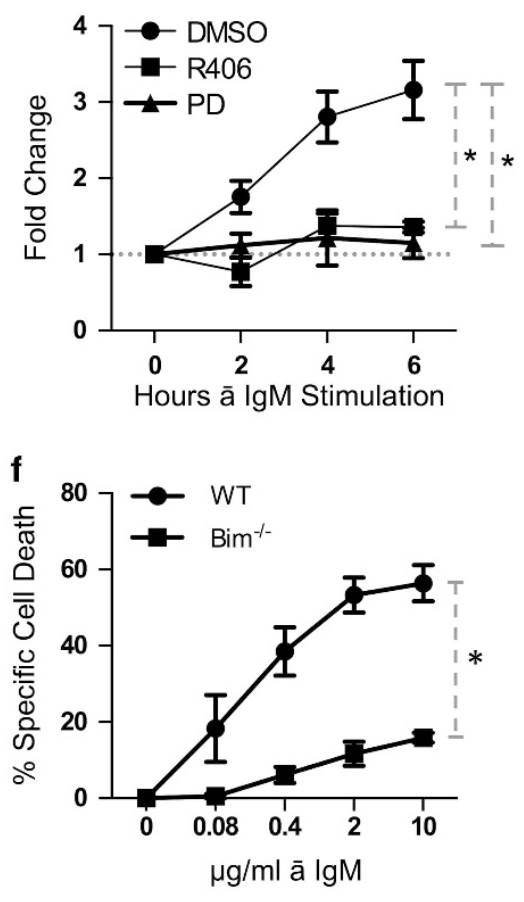

Figure 3 Anti-IgM antibody treatment upregulates Bik and Noxa in addition to Syk/MEK-dependent Bim upregulation. E $\mu$-Myc lymphoma cell lines ( $n=5)$ were subjected to $10 \mu \mathrm{g} / \mathrm{ml} \mathrm{pAb} \overline{\mathrm{a}} \mathrm{IgM} \mathrm{F}(\mathrm{ab})_{2}$ for $0-8 \mathrm{~h}$, RNA harvested, converted to cDNA, and utilized for qPCR analysis of Bim, Bik, and Noxa transcript expression. $n$ denotes the number of different

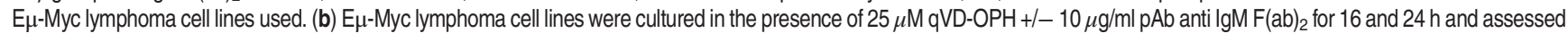
by western blotting for the proteins indicated. Data are representative of three independent experiments using three different E $\mu$-Myc lymphoma cell lines. (c) E $\mu$-Myc lymphoma cell lines were cultured for $24 \mathrm{~h}$ in the presence of $25 \mu \mathrm{M}$ qVD-OPH $+/-10 \mu \mathrm{g} / \mathrm{ml} \mathrm{pAb} \overline{\mathrm{a}} \mathrm{IgM} \mathrm{F}(\mathrm{ab})_{2}$. Cells were then utilized for co-immunoprecipitation studies using anti-Mcl-1 antibody for immunoprecipitation. Immunoprecipitated proteins were determined by western blotting using the antibodies indicated. Data are representative of three independent experiments using three different lymphoma cell lines. WT E $\mu$-Myc lymphoma cell lines $(n=3)$ were cultured as in Figure $1 \mathrm{~b}$ in the absence (d) or presence (e) of $10 \mathrm{nM}$ PD0325901 or $1 \mu \mathrm{M}$ R406 and transcript (d) and protein (e) levels of Bim were analyzed by RT-qPCR and western blotting, respectively. $n$ denotes the number of different E $\mu$-Myc lymphoma cell lines used. ${ }^{*} P<0.05$ by two-way ANOVA statistical analysis. (f) Bim ${ }^{-I}-\mathrm{E} \mu$-Myc lymphoma cell lines $(n=3)$ were cultured as in Figure $1 \mathrm{~b}$ and assessed for cell viability by Annexin V/PI staining followed by flow cytometry. ${ }^{*} P<0.05$ by two-way ANOVA statistical analysis. Data represent the average of three different lymphoma cell lines

Importantly, resistance toward BCR stimulation-induced apoptosis was not a consequence of altered Syk or ERK phosphorylation kinetics following BCR stimulation (Supplementary Figure 4). Furthermore, resistance was specific to the loss of Bik or Noxa, because lymphoma cell lines deficient in Puma, Bid, Bmf, or Bad demonstrated comparable levels of cell death with WT E $\mu$-Myc lymphoma cell lines (Figures 4c and d and Supplementary Figure 9A). Although the maximal level of cell death remained unaffected, $\mathrm{Bad}^{-/-}$and $\mathrm{Bmf}^{-/-} \mathrm{E} \mu-\mathrm{Myc}$ lymphomas exhibited an increased $E_{D} 50$ in comparison with WT (Supplementary Figure 9A). Largely, BH3-only deficient $\mathrm{E} \mu$-Myc lymphomas demonstrated comparable IgM expression with WT, with the exception of $\mathrm{Bad}^{-/-}$(Supplementary figure 9B). Across all genotypes, no correlation between the extent of BCR-induced apoptosis and IgM surface expression level was found (Supplementary Figure 9C). However, the reduced IgM expression exhibited by $\mathrm{Bad}^{-/-}$lymphomas may at least partially explain their reduced sensitivity to BCR stimulation. 

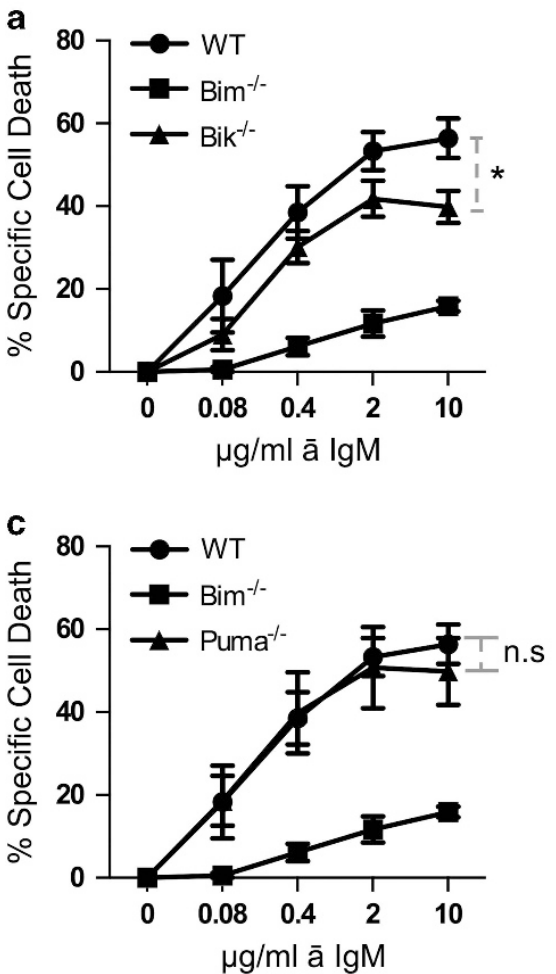
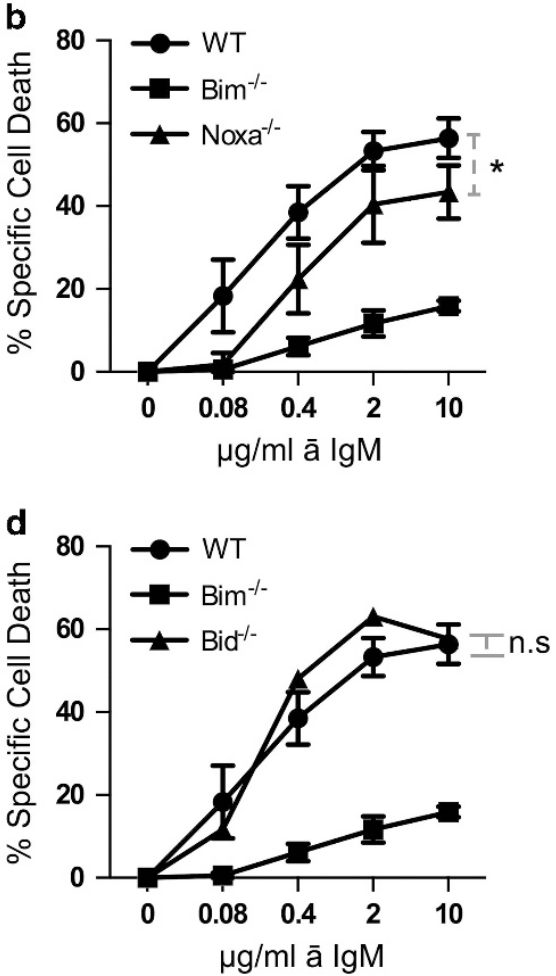

Figure 4 Genetic loss of Bim, Bik, or Noxa significantly impairs BCR-induced killing of E $\mu$-Myc lymphoma cells. E $\mu$-Myc lymphoma cell lines derived from animals deficient in $\operatorname{Bim}(n=3)(\mathbf{a}-\mathbf{d})$, Bik $(n=3)(\mathbf{a})$, Noxa $(n=5)(\mathbf{b})$, Puma $(n=5)(\mathbf{c})$, or Bid $(n=2)(\mathbf{d})$ were cultured as in Figure 1 and sensitivity toward pAb anti-lgM F(ab) 2 was assessed in comparison with WT E $\mu$-Myc lymphoma cell lines $(n=5)$ by Annexin V/PI staining followed by flow cytometry. ${ }^{*} P<0.05$ as assessed by two-way ANOVA statistical analyses. n.s $=$ not significantly different. $n$ denotes the number of different E $\mu$-Myc lymphoma cell lines used per genotype

Concomitant loss of Bim and Noxa enhances resistance to BCR stimulation-induced apoptosis comparable with overexpression of Bcl-2. Retroviral shRNA-mediated Bim RNAi was utilized to generate lymphomas deficient in both Bim and Noxa, or Bim and Bik. Typically, Bim knockdown was $75 \%$ or greater across all genotypes and Bik and Noxa transcript upregulation was maintained following BCR stimulation (Figure 5a and data not shown). As anticipated, Bim knockdown imparted extensive resistance toward BCR-induced apoptosis in WT E $\mu$-Myc lymphomas, whereas empty vector controls were comparable with non-transduced cell lines (Figure $5 b$ ). Consistent with a role in BCR-induced apoptosis, Bim knockdown in both $\mathrm{Bik}^{-1-}$ and $\mathrm{Noxa}^{-1-}$ E $\mu$-Myc lymphomas yielded greater resistance than Bim knockdown alone (Figure 5c). Although the effect of combined loss of Bim and Bik was slight, a significant trend toward enhanced resistance was evident at all concentrations of anti-IgM antibody (Figure 5c). In contrast, Bim knockdown

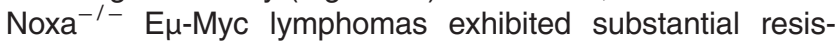
tance, yielding a level of resistance toward BCR-induced cell death comparable with that produced by Bcl-2 overexpression (Figure 5c).

\section{Discussion}

Data presented here demonstrate that upregulation of Bim, Noxa, and Bik drives maximal killing during BCR-induced apoptosis in Eu-Myc lymphoma cells. In agreement with previous studies, we identify that caspase-independent initialization of MOMP precedes a caspase-activation cascade that directly initiates cellular execution. ${ }^{8,44,45}$ Taken alongside data demonstrating that $\mathrm{Bcl}-2$ overexpression causes complete resistance to BCR-induced cell death (Figure $1 \mathrm{~b}$ and ${ }^{10}$ ), such data directly link the BCR to the intrinsic/mitochondrial pathway of apoptosis. Following MOMP, we observed substantial activation of initiator caspases-2 and -9 and effector caspases-3, -6 , and -7 . The exact identity of the key BCRinduced initiator caspase remains unclear, ${ }^{8,9,44}$ largely from an inability to rule out the possibility that BCR-induced caspase-2 cleavage (indicative of its activation) results directly from positive feedback via effector caspases. ${ }^{8,44}$ Furthermore, observations that mice deficient in caspase-2, caspase-9, or mice possessing a caspase- $2^{-1-}$; caspase- $9^{-1-}$ hematopoietic system do not exhibit autoimmune pathology indicates that deletion of autoreactive B-cells (by BCR-induced apoptosis) occurs normally in their absence. ${ }^{46,47}$ Therefore, it is likely that either the caspase activation pathway downstream of the BCR exhibits redundancy or that caspase-independent mechanisms suffice to cause cell death.

In agreement with previous studies, our data identify Bim as the major driver of BCR-induced apoptosis, ${ }^{10,32,33}$ reflected in the widespread dysregulation of $\mathrm{B}$-lymphocyte homeostasis in $\mathrm{Bim}^{-1-}$ mice. ${ }^{10,22}$ Indeed, BCR stimulation-driven Bim upregulation has been attributed to a combination of transcriptional upregulation and isoform skewing, via JNK-dependent alternative splicing and Bim $\mathrm{EL}_{\mathrm{L}}$ protein degradation, toward expression of the more highly pro-apoptotic Bim $_{L}$ isoform. ${ }^{32,33}$ However, recent studies demonstrate that such alternative 
a

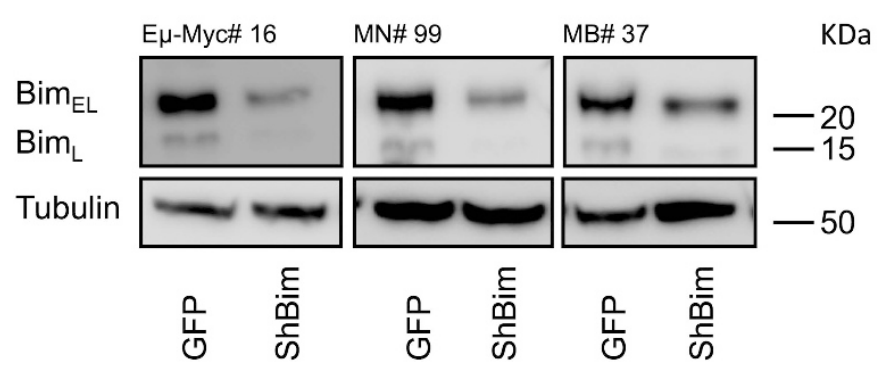

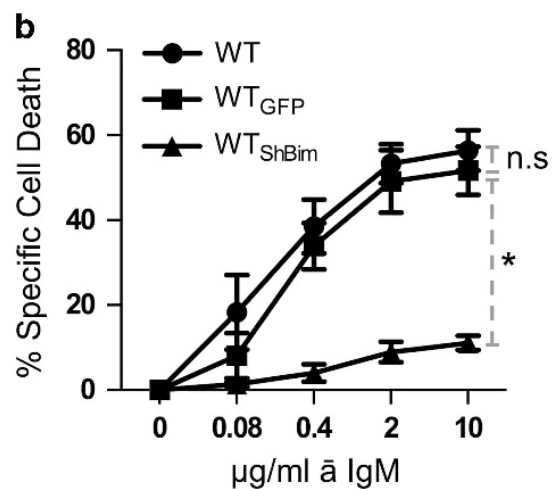
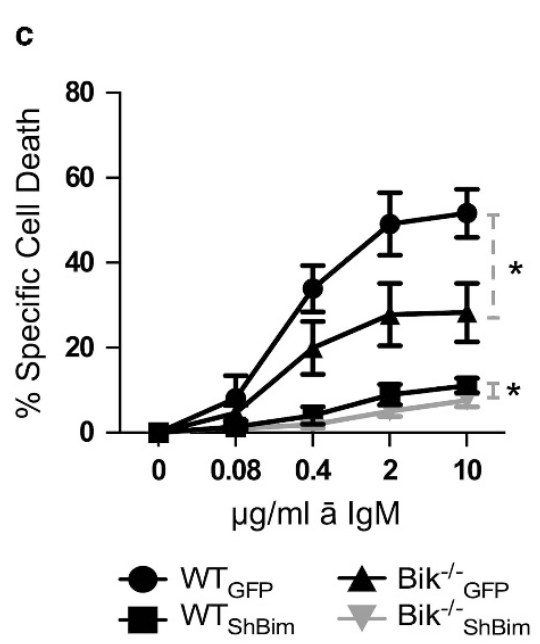
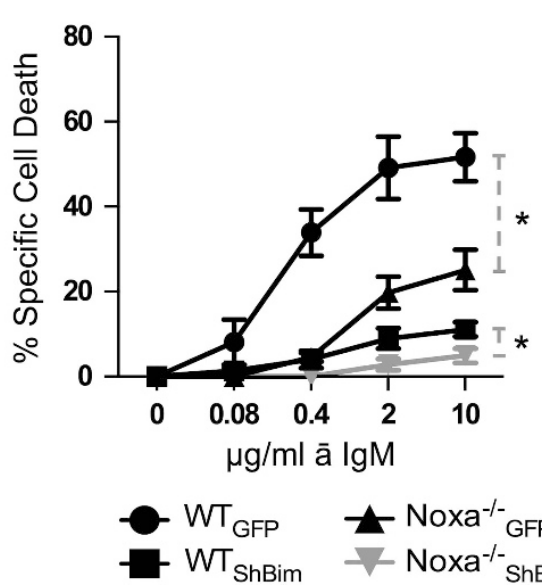

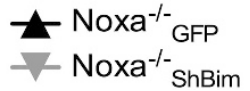

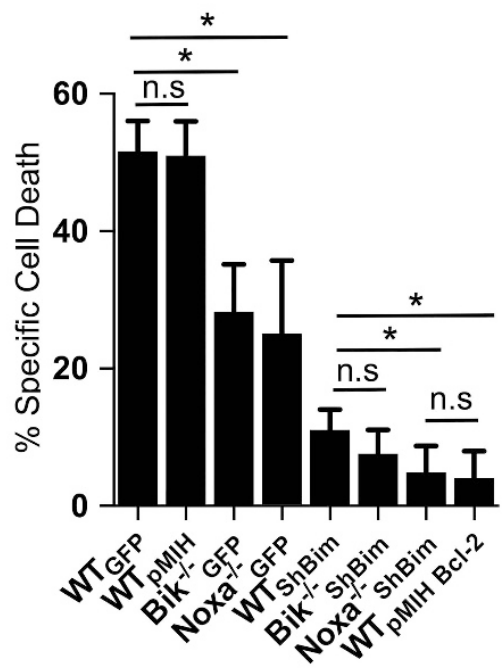

Figure 5 Combined loss of Bim and Noxa, and to a lesser extent combined loss of Bim and Bik, yields greater resistance toward BCR-induced killing of E $\mu$-Myc lymphoma cells than loss of Bim alone. WT, Bik-, or Noxa-deficient $\mathrm{E} \mu$-Myc lymphoma cells were retrovirally transduced with an ShBim RNA encoding construct or empty vector control (GFP). Bim knockdown was approximately $75 \%$ regardless of genotype of the lymphoma cells as assessed by western blotting (a). MN\# $99=E \mu-M y c$ Noxa ${ }^{-1}-\# 99$, MB\# $37=E \mu-M y c B B^{-I-} \# 37$. Data for each genotype of $\mathrm{E} \mu-M y c$ lymphoma are representative of all $E \mu-M y c$ lymphoma cell lines transduced ( $\left.n=9\right)$. Subsequently, ShBim/GFP control encoding E $\mu$-Myc lymphoma cells from WT (b) $(n=3)$, Bik ${ }^{-1-}(n=3)$ (c left panel), or Noxa ${ }^{-1-}(n=3)$ (c center panel) backgrounds were assessed for sensitivity to BCR-induced cell death by Annexin V/PI staining followed by flow cytometry after $24 \mathrm{~h} .{ }^{*} P<0.05$ by two-way ANOVA statistical analysis (b, c left and center panels) or by unpaired Student's T-test statistical analysis (c right panel). $n$ denotes the number of different E $\mu$-Myc lymphoma cell lines used per genotype

splicing mechanisms are largely dispensable for Bim function. ${ }^{48}$ In $\mathrm{E} \mu$-Myc lymphomas, BCR-mediated Bim upregulation occurred primarily via a Syk/MEK/ERK-dependent transcriptional mechanism, whereas inhibition of JNK had little effect (data not shown). Although well documented, the exact nature of ERK-mediated regulation of Bim remains unclear. It was initially proposed that ERK functions as a prosurvival, posttranslational modifier of Bim via direct phosphorylation of $\mathrm{Ser}^{69}$ resulting in polyubiquitination, proteasomal targeting, and reduced $\mathrm{Bim}_{\mathrm{EL}}$ expression. ${ }^{49-51}$ However, mice exhibiting mutations within the Bim $\mathrm{EL}_{\mathrm{L}}$ DEF2 domain (which abrogate ERK:Bim docking) demonstrate normal hematopoietic homeostasis and apoptotic sensitivity. ${ }^{48}$ These studies demonstrate that although ERKmediated Bim $_{E L}$ degradation is evident in vitro following certain apoptotic stimuli, it is dispensable for Bim function in vivo. Alternatively, it is suggested that ERK may regulate Bim transcriptionally by a mechanism centered upon the 3' UTR of Bim mRNA in sympathetic neurons and may directly influence miRNA-mediated control of Bim expression in nonsmall cell lung carcinomas. ${ }^{52,53}$
Regardless of the exact mechanism, ERK is largely associated with a negative regulatory impact upon Bim expression. Such a role is most likely reflected in our observation that MEK inhibition in both normal and preneoplastic Myc-Tg B-lymphocytes exacerbated BCR-induced cell death (Supplementary Figure 5A). Therefore, it appears BCR-mediated Bim transactivation occurs via a lymphomaspecific, ERK-dependent mechanism in E $\mu$-Myc lymphoma cells. Indeed, altered MAPK signaling kinetics have been observed in malignant lymphoma cells in comparison with their non-transformed counterparts. ${ }^{54}$ Whether these observed differences contribute toward lymphoma-specific cellular outcomes remains a topic of ongoing research.

Our data therefore imply that pharmacological activation of ERK signaling, akin to that produced upon BCR-induced cell death, may prove a successful combination therapy alongside PI3K inhibitors, such as Idelalisib, because PI3K inhibition failed to influence the extent of BCR-induced cell killing.

Although we demonstrated that Bim has a major role downstream of the $B C R$, its genetic loss did not yield resistance equivalent to that produced upon $\mathrm{Bcl}-2$ overexpression, as 
described previously in an alternate system. ${ }^{10}$ Therefore, BCR engagement likely activates additional $\mathrm{BH} 3-$ only proteins to achieve maximal apoptosis. Our data suggest minor but significant roles for both Noxa and Bik in BCR-induced apoptosis. Although a role for Bik downstream of the BCR has long been suspected but poorly defined, ${ }^{55}$ the implication of Noxa represents a novel finding. However, in recent years, a putative co-operative relationship between Bim and Noxa has become apparent downstream of antigen receptors. Indeed, transcriptional upregulation of Noxa has been observed following the activation of both $\mathrm{B}$ - and T-cell antigen receptors and a co-operative role in T-cell receptor (TCR) stimulationinduced apoptosis has been demonstrated alongside Bim and Puma. ${ }^{26,27,30,56}$ Furthermore, Noxa appears to sensitize lymphocytes with low-affinity antigen receptors toward cell death during the germinal center reaction. ${ }^{26}$ Such observations, along with our own, imply the existence of a conserved pathway linking antigen receptor activation to transcriptional regulation of Bim and Noxa. Noxa transcript regulation is most often associated with p53 transactivation, ${ }^{57,58}$ however, additional p53-independent processes involving $\mathrm{HIF} a^{59}$ and $\mathrm{PKC}^{60}$ have also been documented among others. It is possible that BCRinduced Noxa transactivation occurs via a PKC-dependent mechanism, because although Syk activity was dispensable for Noxa transactivation, Bruton's Tyr Kinase (Btk) activity may be sufficient to drive PLC $\gamma 2-$ mediated PKC activation. ${ }^{61}$ Interestingly, the combined loss of Noxa and Bim (but not combined loss of Bik and Bim) yielded resistance to BCR-induced apoptosis statistically identical to that produced with $\mathrm{hBcl}-2$ overexpression. These data implicate Noxa as a key inducer of MOMP (in addition to Bim) following BCR ligation, consistent with its purported direct activator function. ${ }^{62}$ However, such activity remains disputed and would not explain the apparently normal phenotype of $\mathrm{Noxa}^{-1-}$ mice. ${ }^{57} \mathrm{~A}$ more likely situation is reflected in the ability of Noxa to target $\mathrm{Mcl}-1$ for proteasomal degradation ${ }^{63}$ resulting in MOMP via a reduction in pro-survival protein inhibition of Bax/Bak oligomerization. Indeed, observations of BCR-induced $\mathrm{Mcl}-1$ degradation in $\mathrm{E} \mu$-Myc lymphoma cell lines appear to corroborate this (Supplementary Figure 6C). However, whether Mcl-1 degradation alone, without BH3-only protein-mediated activation of Bax/ Bak, is capable of inducing MOMP remains debatable. Whereas elevated levels of Noxa transcripts were sustained following BCR stimulation in $\mathrm{E} \mu-\mathrm{Myc}$ lymphomas, the human lymphoma cell line Daudi, and normal murine B-lymphocytes, a shorter duration of response was evident in Ramos cells (Supplementary Figures 8A and B). However, in Ramos, Noxa protein upregulation at the protein level was evident at later time points, which did not correlate with increased transcript levels (Supplementary Figure $8 \mathrm{C}$ and data not shown). Therefore, both transcriptional and nontranscriptional mechanisms may exist linking BCR stimulation to Noxa upregulation.

Our data suggest a lesser role for Bik downstream of the BCR. Although BCR-induced Bik upregulation has been previously observed, ${ }^{55}$ studies to abrogate Bik expression in lymphoma cells have been lacking. Studies in $\mathrm{Bik}^{-/-}$mice demonstrated that Bik appears dispensable for apoptotic responses to many cell death stimuli in non-transformed B-lymphocytes, including BCR stimulation. ${ }^{64,65}$ However, in recent years, Bik has been implicated in B-cell homeostatic control in both malignant and non-neoplastic B-lymphocytes, via its involvement in TGF- $\beta$-induced cell death. ${ }^{66}$ In a malignant setting, we and others demonstrate conserved upregulation of Bik transcripts downstream of BCR stimulation in multiple models (Figure $3 a$ and Supplementary Figures 7 and 8$),{ }^{55}$ and here for the first time, we show a reduction in BCR-induced killing of $\mathrm{E} \mu$-Myc lymphoma cells following loss of Bik. It is therefore likely that BCR-signaling-induced cell death has different $\mathrm{BH} 3-$ only requirements, or at least different kinetics of $\mathrm{BH} 3-o n l y$ induction, in alternate cellular contexts. In support of this, we demonstrate a delayed upregulation of Bik transcripts in normal lymphocytes, in comparison with malignant B-cell models (Figure 3 and Supplementary Figures 7 and 8). Consequently, a functional role for Bik downstream of the BCR may be restricted to malignant lymphocytes, explaining the apparently normal sensitivity of $\mathrm{Bik}^{-1-} \mathrm{B}$ cells toward BCR stimulation. ${ }^{65}$ It is conceivable that differences in BCR-induced signaling pathways between normal and neoplastic B-lymphocytes may invoke alternate cell death pathways downstream of the BCR. ${ }^{54}$

Although our data suggest that Bik alone is unable to drive cell death, it appears to perform a sensitization role downstream of the BCR consistent with its role as a sensitizer BH3-only protein. ${ }^{67}$ We therefore propose that although Bim represents the major executioner downstream of the BCR, both Noxa and to a lesser extent Bik perform sensitization roles.

\section{Materials and Methods}

Mice. $E \mu-M y c ~ T g$ mice were described previously. ${ }^{68}$ SCID/NOD mice were obtained from the Jackson Laboratory (Bar Harbour, ME, USA) and intercrossed with $\mathrm{Fc} \gamma \mathrm{R}^{-1-}$ mice (kind gift from Dr Sjef Verbeek, Leiden) to produce SCID/NOD $\mathrm{Fc}_{\mathrm{R}} \mathrm{R}^{-l-}$ mice. Mice were maintained in local facilities and experiments approved by local ethical committee under Home Office licenses PPL30/2450 and 30/2451. $\mathrm{SCID} / \mathrm{NOD} \mathrm{Fc} \gamma \mathrm{R}^{-1}$ mice received $1 \times 10^{6} \mathrm{E} \mu$-Myc tumor cells i.v. at 8 weeks of age. Transplanted tumors presented with identical symptoms to spontaneously occurring tumors.

Cell line derivation and tissue culture. Splenocytes from tumor-bearing E $\mu$-Myc Tg mice were cultured in DMEM (Life Technologies, Paisley, UK) supplemented with $10 \%$ fetal calf serum (Lonza, Slough, UK), $50 \mu \mathrm{M} 2$ Mercaptoethanol (Sigma, Gillingham, UK), $200 \mu \mathrm{M} \mathrm{L-Asparagine} \mathrm{(Sigma),} 1 \mathrm{mM}$ Pyruvate (Life Technologies), $2 \mathrm{mM}$ Glutamine (Life Technologies), 45 units $/ \mathrm{ml}$ Penicillin, and $45 \mu \mathrm{g} / \mathrm{ml}$ Streptomycin at $37^{\circ} \mathrm{C}, 10 \% \mathrm{CO}_{2}$.

Antibodies and inhibitors. Polyclonal goat anti-mouse/human IgM specific $\mathrm{F}(\mathrm{ab}){ }_{2}$ (Jackson Immunotech, West Grover, PA, USA) was utilized for in vitro BCR stimulation. Monoclonal rat-anti-mouse IgM (IgG2a: clone Mc39.12) was produced in-house, and utilized in vivo ( $3 \times 125 \mu \mathrm{g}$ i.v. injections on days 7,14 , and 21 post tumor). Antibodies used for western blot analysis are detailed in the Supplementary methods. qVD-OPH was obtained from MP Biochemicals (Santa Ana, CA, USA). R406 and PD0325901 were obtained from Selleck Chemicals (Houston, TX, USA).

Cell viability assays. Annexin V/propidium iodide (PI) assays were performed as previously described. ${ }^{69,70}$ Briefly, cells were re-suspended at $0.6 \times 10^{6} \mathrm{cells} / \mathrm{ml}$ and subjected to the indicated concentration of antibody/drug for $24 \mathrm{~h}$, harvested and stained in medium with Annexin $\mathrm{V}^{\mathrm{FITC}}(1 \mu \mathrm{g} / \mathrm{ml})$ and PI $(3.6 \mu \mathrm{g} / \mathrm{ml}$, Sigma) for $15 \mathrm{~min}$ and analyzed on a FACScan (BD Biosciences, Oxford, UK) flow cytometer. $\mathrm{DiOC}_{6} / \mathrm{PI}$ staining was performed by addition of $\mathrm{DiOC}_{6}$ (Life Technologies) to cells at $10 \mathrm{nM} 30 \mathrm{~min}$ prior to harvesting. Cells were harvested, washed, and resuspended in medium containing PI $(3.6 \mu \mathrm{g} / \mathrm{ml})$ and analyzed by flow cytometry. Stimulus-specific cell death/ $\Psi \mathrm{m}$ was calculated by 100-((viability/vehicle-treated viability) $\times 100$ ). 
Quantitative PCR. RNA was purified using Purelink RNA-mini kit (Life Technologies) and quality-assessed using the Agilent 2100 Bioanalyzer (Agilent, Santa Clara, CA, USA). RNA was converted to CDNA using the Superscript first-strand synthesis kit (Life Technologies) and combined with Taqman gene expression assays (Supplementary methods for assay ID), qPCR supermix UND (Life Technologies), and analyzed using a Bio-Rad CFX96 (Bio-Rad, Hemel-Hempstead, UK). Data were converted to fold change using the $2^{-\Delta \Delta c T}$-normalization method using GAPDH as a reference.

Western blotting and immunoprecipitation. Cells were lysed in RIPA

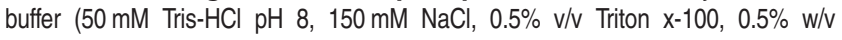
Deoxycholate, $0.1 \%$ SDS, $50 \mathrm{mM} \mathrm{NaF}, 2 \mathrm{mM} \mathrm{NaVO}_{4}$ ) and subjected to western blotting using standard techniques. For immunoprecipitation, $1 \times 10^{8}$ cells per sample were lysed in CHAPS lysis buffer $(20 \mathrm{mM}$ Tris pH 7.4, $142.5 \mathrm{mM} \mathrm{KCl}, 2 \mathrm{mM}$ $\mathrm{CaCl}_{2}, 1 \%$ CHAPS). Five hundred micrograms of protein were adjusted to $500 \mu \mathrm{l}$ and pre-cleared via addition of $50 \mu \mathrm{l} 50 \% \mathrm{v} / \mathrm{v}$ Protein G Sepharose in CHAPS lysis buffer for $2 \mathrm{~h}$ at $4{ }^{\circ} \mathrm{C}$. Concurrently, Protein $\mathrm{G}$ Sepharose was blocked by incubation with $5 \%$ normal Rat serum for $2 \mathrm{~h}$ at $4^{\circ} \mathrm{C}$. Pre-cleared lysates and blocked beads were subsequently pelleted by centrifugation and the relevant fractions retained. Pre-cleared lysates were then incubated with $50 \mu$ l blocked protein G Sepharose and $5 \%$ normal rat serum for $2 \mathrm{~h}$ at $4{ }^{\circ} \mathrm{C}$, after which samples were centrifuged and the beads discarded. Simultaneously, $50 \mu \mathrm{l}$ blocked protein $\mathrm{G}$ Sepharose was incubated with a sufficient amount of antibody to give a final concentration (when applied to lysates) of $2 \mu \mathrm{g} / \mathrm{ml}$ for $2 \mathrm{~h}$ at $4^{\circ} \mathrm{C}$. Lysates were then centrifuged, the bead pellet discarded, and $50 \mu \mathrm{l}$ of the antibody bead mixtures added to lysates and mixed overnight at $4^{\circ} \mathrm{C}$ with agitation. Beads were subsequently pelleted, retained, and washed five times in lysis buffer followed by incubation with reducing $2 \times$ Laemmli buffer and boiled for $5 \mathrm{~min}$. Lysates were then analyzed by SDS-PAGE and western blotting using Tru-Blot HRP-conjugated antibodies (eBioscience, Hatfield, UK) as the secondary reagents.

Generation of ShRNA or Bcl-2 expressing E $\mu$-Myc lymphoma cells. For generation of Bim knockdown or Bcl-2 overexpressing E $\mu$-Myc lymphomas, a retroviral spin-infection protocol was used as described previously. ${ }^{69}$ Ecotropic $\phi$ nix cells were grown in DMEM supplemented with $10 \%$ fetal calf serum, $2 \mathrm{mM}$ Glutamine, $1 \mathrm{mM}$ Pyruvate, $45 \mathrm{units} / \mathrm{ml}$ Penicillin, and $45 \mu \mathrm{g} / \mathrm{ml}$ Streptomycin at $37^{\circ} \mathrm{C}, 10 \% \mathrm{CO}_{2}$. $\phi$ nix cells were incubated with $5 \mu \mathrm{M}$ Chloroquine for 5 min prior to transfection via $\mathrm{Ca}^{2+}$ : phosphate precipitation. Retroviral constructs based on murine stem cell virus (MscV) puro IRES/GFP (pMscV.Puro.Ires.GFP) and MscV IRES hygro (pMIH) were utilized containing ShBim and Bcl-2 constructs, respectively. Ten micrograms of pMIH-Bcl-2 or pMscV.Puro.Ires.GFP ShBim (or empty vectors) were diluted alongside $4 \mu \mathrm{g}$ p.CL-Eco in HEPES-buffered saline followed by addition of $\mathrm{CaCl}_{2}$ to $120 \mathrm{mM}$. Mixtures were applied to pnix cells and incubated at $37^{\circ} \mathrm{C}, 5 \% \mathrm{CO}_{2}$ for $8 \mathrm{~h}$, before the medium was replaced, left for $48 \mathrm{~h}$ and viral supernatants collected. Polybrene was added to viral supernatants at $4 \mu \mathrm{g} / \mathrm{ml}$ and $1.5 \mathrm{ml}$ supernatant added to $6 \times 10^{5} \mathrm{E} \mu-M y c$ lymphoma cells, before centrifugation at $180 \times \mathrm{g}, 37^{\circ} \mathrm{C}$ for $45 \mathrm{~min}$. Cells were then incubated at $37^{\circ} \mathrm{C}$, $10 \% \mathrm{CO}_{2}$ for $48 \mathrm{~h}$. Puromycin $(1 \mu \mathrm{g} / \mathrm{ml})$ or Hygromycin $(250 \mu \mathrm{g} / \mathrm{ml})$ was then added for 7 days. The top $5 \%$ of GFP-positive transduced cells were then sorted (FACSaria). Bcl-2 overexpression was confirmed by intracellular flow cytometry.

Statistical analysis. Data are expressed as mean \pm S.E.M. Statistical significance between two groups was assessed by either paired/un-paired Student's $T$-test. For experiments involving multiple variables, statistical significance was assessed via two-way ANOVA. Survival was assessed via Mantel-Cox statistical analysis.

\section{Conflict of Interest}

MSC acts as a consultant to Bioinvent International and has received grant funding from them. He has previously served as an ad hoc consultant for Roche and has also received grant funding from Roche-Glycart. AS acts as a consultant for Genentech. The remaining authors declare no conflict of interest.

Acknowledgements. We would like to thank Patrick Duriez (Protein Engineering Group, CRUK center, Southampton) for the provision of annexin V-FITC. This work was supported by a MRC studentship to MJC., Leukaemia \& Lymphoma Research grants to MSC (04006 and 07048) and GKP (11023), a National Health and Medical Research Council program grant to AS (program grant
1016701; NHMRC Fellowship 1020363,) and the Leukemia and Lymphoma Society grant to AS (SCOR Grant 7001-03).

\section{Author contributions}

MJC performed the research, analyzed the data and wrote the manuscript. KLC aided in in vivo studies. SJB and YDB aided in the generation of plasmid vectors, $\mathrm{LH}$ and CS initially characterized and provided BH3-only protein deficient lymphomas. GKP and AS provided guidance and aided in manuscript preparation. MSC coordinated the study, interpreted the data and wrote the manuscript with MJC. All authors read and commented on the manuscript.

1. Carsetti R, Rosado MM, Wardemann H. Peripheral development of B cells in mouse and man. Immunol Rev 2004; 197: 179-191.

2. Lam KP, Kuhn R, Rajewsky K. In vivo ablation of surface immunoglobulin on mature $B$ cells by inducible gene targeting results in rapid cell death. Cell 1997; 90: 1073-1083.

3. Srinivasan L, Sasaki Y, Calado DP, Zhang B, Paik JH, DePinho RA et al. PI3 kinase signals BCR-dependent mature B cell survival. Cell 2009; 139: 573-586.

4. Nemazee DA, Burki K. Clonal deletion of Lymphocyte-B in a transgenic mouse bearing antiMHC Class-I antibody genes. Nature 1989; 337: 562-566.

5. Goodnow CC, Crosbie J, Adelstein S, Lavoie TB, Smith-Gill SJ, Brink RA et al. Altered Immunoglobulin expression and functional silencing of self-reactive B-lymphocytes in transgenic mice. Nature 1988; 334: 676-682.

6. Hartley SB, Crosbie J, Brink R, Kantor AB, Basten A, Goodnow CC. Elimination from peripheral lymphoid-tissues of self-reactive B-lymphocytes recognizing membrane-bound antigens. Nature 1991; 353: 765-769.

7. Hardy RR, Hayakawa K. B cell development pathways. Annu Rev Immunol 2001; 19: 595-621.

8. Eldering E, Mackus WJM, Derks IAM, Evers LM, Beuling E, Teeling P et al. Apoptosis via the $B$ cell antigen receptor requires $B$ ax translocation and involves mitochondrial depolarization, cytochrome C release, and caspase-9 activation. Eur J Immunol 2004; 34: 1950-1960.

9. Berard R, Mondiere P, Casamayor-Palleja M, Hennino A, Bella C, Defrance T. Mitochondria connects the antigen receptor to effector caspases during $B$ cell receptor-induced apoptosis in normal human B cells. J Immunol 1999; 163: 4655-4662.

10. Enders $A$, Bouillet $P$, Puthalakath $H, X U$ YK , Tarlinton DM, Strasser $A$. Loss of the proapoptotic BH3-only Bcl-2 family member Bim inhibits BCR stimulation-induced apoptosis and deletion of autoreactive B cells. J Exp Med 2003; 198: 1119-1126.

11. Vuist WMJ, Levy R, Maloney DG. Lymphoma regression induced by monoclonal antiidiotypic antibodies correlates with their ability to induce signal-transduction and is not prevented by tumor expression of high levels of Bcl-2 protein. Blood 1994; 83: 899-906.

12. Advani RH, Buggy JJ, Sharman JP, Smith SM, Boyd TE, Grant B et al. Bruton tyrosine kinase inhibitor ibrutinib (PCI-32765) has significant activity in patients with relapsed/ refractory B-cell malignancies. J Clin Oncol 2013; 31: 88-94

13. Czabotar PE, Lessene G, Strasser A, Adams JM. Control of apoptosis by the BCL-2 protein family: implications for physiology and therapy. Nat Rev Mol Cell Biol 2014; 15 . 49-63.

14. Zou H, Li YC, Liu HS, Wang XD. An APAF-1 center dot cytochrome c multimeric complex is a functional apoptosome that activates procaspase-9. J Biol Chem 1999; 274: 11549-11556.

15. Zong WX, Lindsten T, Ross AJ, MacGregor GR, Thompson CB. BH3-only proteins that bind pro-survival $\mathrm{Bcl}-2$ family members fail to induce apoptosis in the absence of Bax and Bak. Genes Dev 2001; 15: 1481-1486.

16. Wei MC, Zong WX, Cheng EH, Lindsten T, Panoutsakopoulou V, Ross AJ et al. Proapoptotic BAX and BAK: A requisite gateway to mitochondrial dysfunction and death. Science 2001; 292: $727-730$

17. Antonsson B, Montessuit S, Lauper S, Eskes R, Martinou JC. Bax oligomerization is required for channel-forming activity in liposomes and to trigger cytochrome $\mathrm{C}$ release from mitochondria. Biochem J 2000; 345: 271-278.

18. Willis SN, Fletcher JI, Kaufmann T, van Delft MF, Chen L, Czabotar PE et al. Apoptosis initiated when BH3 ligands engage multiple Bcl-2 homologs, not Bax or Bak. Science 2007; 315: 856-859.

19. Cheng E, Wei MC, Weiler S, Flavell RA, Mak TW, Lindsten T et al. BCL-2, BCL-X-L sequester $\mathrm{BH} 3$ domain-only molecules preventing BAX- and BAK-mediated mitochondrial apoptosis. Mol Cell 2001; 8: 705-711.

20. Strasser A. The role of BH3-only proteins in the immune system. Nat Rev Immunol 2005; 5 : $189-200$.

21. Afshar-Sterle S, Zotos D, Bernard NJ, Scherger AK, Rödling L, Alsop AE et al. Fas ligandmediated immune surveillance by $T$ cells is essential for the control of spontaneous B cell lymphomas. Nat Med 2014; 20: 283-290.

22. Bouillet $\mathrm{P}$, Metcalf D, Huang DC, Tarlinton DM, Kay TW, Köntgen F et al. Proapoptotic Bcl-2 relative bim required for certain apoptotic responses, leukocyte homeostasis, and to preclude autoimmunity. Science 1999; 286: 1735-1738.

23. Ogilvy S, Metcalf D, Print CG, Bath ML, Harris AW, Adams JM. Constitutive Bcl-2 expression throughout the hematopoietic compartment affects multiple lineages and enhances progenitor cell survival. Proc Natl Acad Sci USA 1999; 96: 14943-14948. 
24. Erlacher M, Labi V, Manzl C, Böck G, Tzankov A, Häcker G et al. Puma cooperates with Bim, the rate-limiting $\mathrm{BH}$-only protein in cell death during lymphocyte development, in apoptosis induction. J Exp Med 2006; 203: 2939-2951.

25. Labi V, Erlacher M, Kiessling S, Manzl C, Frenzel A, O'Reilly L et al. Loss of the BH3-only protein Bmf impairs $B$ cell homeostasis and accelerates gamma irradiation-induced thymic lymphoma development. J Exp Med 2008; 205: 641-655.

26. Wensveen FM, Derks IA, van Gisbergen KP, de Bruin AM, Meijers JC, Yigittop H et al. BH3only protein Noxa regulates apoptosis in activated $B$ cells and controls high-affinity antibody formation. Blood 119: 1440-1449.

27. Wensveen FM, van Gisbergen KPJM, Derks IA, Gerlach C, Schumacher TN, van Lier RA et al. Apoptosis threshold set by Noxa and Mcl-1 after T cell activation regulates competitive selection of high-affinity clones. Immunity 2010; 32: 754-765.

28. Huebner A, Cavanagh-Kyros J, Rincon M, Flavell RA, Davis RJ. Functional cooperation of the proapoptotic Bcl2 family proteins Bmf and Bim in vivo. Mol Cell Biol 2010; 30: 98-105.

29. Clybouw C, Fischer S, Auffredou MT, Hugues P, Alexia C, Bouillet $P$ et al. Regulation of memory B-cell survival by the BH3-only protein Puma. Blood 118: 4120-4128.

30. Gray DH, Kupresanin F, Berzins SP, Herold MJ, O'Reilly LA, Bouillet P et al. The BH3-only proteins Bim and Puma cooperate to impose deletional tolerance of organ-specific antigens. Immunity 2012; 37: 451-462.

31. Kroesen BJ, Pettus B, Luberto C, Busman M, Sietsma H, de Leij L et al. Induction of apoptosis through $\mathrm{B}$-cell receptor cross-linking occurs via de novo generated $\mathrm{C} 16$-ceramide and involves mitochondria. J Biol Chem 2001; 276: 13606-13614.

32. Mouhamad S, Besnault L, Auffredou MT, Leprince C, Bourgeade MF, Leca G et al. B cell receptor-mediated apoptosis of human lymphocytes is associated with a new regulatory pathway of Bim isoform expression. J Immunol 2004; 172: 2084-2091.

33. Takada E, Hata K, Mizuguchi J. Requirement for JNK-dependent upregulation of BimL in anti-IgM-induced apoptosis in murine B lymphoma cell lines WEHI-231 and CH31. Exp Cell Res 2006; 312: 3728-3738.

34. Beers SA, French RR, Chan HT, Lim SH, Jarrett TC, Vidal RM et al. Antigenic modulation limits the efficacy of anti-CD20 antibodies: implications for antibody selection. Blood 2010; 115: 5191-5201.

35. Schuster C, Berger A, Hoelzl MA, Putz EM, Frenzel A, Simma O et al. The cooperating mutation or "second hit" determines the immunologic visibility toward MYC-induced murine lymphomas. Blood 2011; 118: 4635-4645.

36. Oreilly $L A$, Huang DC, Strasser A. The cell death inhibitor Bcl-2 and its homologues influence control of cell cycle entry. EMBO J 1996; 15: 6979-6990.

37. Rong Y-P, Bultynck G, Aromolaran AS, Zhong F, Parys JB, De Smedt $\mathrm{H}$ et al. The BH4 domain of $\mathrm{Bcl}-2$ inhibits $\mathrm{ER}$ calcium release and apoptosis by binding the regulatory and coupling domain of the IP3 receptor. Proc Natl Acad Sci USA 2009; 106: 14397-14402.

38. Cande C, Cohen I, Daugas E, Ravagnan L, Larochette N, Zamzami N et al. Apoptosisinducing factor (AIF): a novel caspase-independent death effector released from mitochondria. Biochimie 2002; 84: 215-222.

39. Saleh A, Srinivasula SM, Acharya S, Fishel R, Alnemri ES. Cytochrome $\mathrm{c}$ and dATP. mediated oligomerization of Apaf- 1 is a prerequisite for procaspase-9 activation. J Biol Chem 1999; 274: 17941-17945.

40. Li LY, Luo L, Wang XD. Endonuclease $G$ is an apoptotic DNase when released from mitochondria. Nature 2001; 412: 95-99.

41. Askew DS, Ashmun RA, Simmons BC, Cleveland JL. Constitutive c-Myc expression in an IL-3-dependent myeloid cell-line suppresses cell-cycle arrest and accelerates apoptosis. Oncogene 1991; 6: 1915-1922.

42. Coultas L, Terzano S, Thomas T, Voss A, Reid K, Stanley EG et al. Hrk/DP5 contributes to the apoptosis of select neuronal populations but is dispensable for haematopoietic cell apoptosis. J Cell Sci 2007; 120: 2044-2052.

43. Happo L, Phipson B, Smyth GK, Strasser A, Scott CL. Neither loss of Bik alone, nor combined loss of Bik and Noxa, accelerate murine lymphoma development or render lymphoma cells resistant to DNA damaging drugs. Cell Death Dis 3: e306.

44. Chen WP, Wang HG, Srinivasula SM, Alnemri ES, Cooper NR. B cell apoptosis triggered by antigen receptor ligation proceeds via a novel caspase-dependent pathway. J Immunol 1999; 163: 2483-2491.

45. Herold MJ, Kuss AW, Kraus C, Berberich I. Mitochondria-dependent caspase-9 activation is necessary for antigen receptor-mediated effector caspase activation and apoptosis in WEHI 231 lymphoma cells. J Immunol 2002; 168: 3902-3909.

46. O'Reilly LA, Ekert P, Harvey N, Marsden V, Cullen L, Vaux DL et al. Caspase-2 is not required for thymocyte or neuronal apoptosis even though cleavage of caspase-2 is dependent on both Apaf-1 and caspase-9. Cell Death Differ 2002; 9: 832-841.
47. Marsden VS, Ekert PG, Van Delft M, Vaux DL, Adams JM, Strasser A. Bcl-2-regulated apoptosis and cytochrome $c$ release can occur independently of both caspase-2 and caspase-9. J Cell Biol 2004; 165: 775-780.

48. Clybouw C, Merino D, Nebl T, Masson F, Robati M, O'Reilly L et al. Alternative splicing of Bim and Erk-mediated Bim(EL) phosphorylation are dispensable for hematopoietic homeostasis in vivo. Cell Death Differ 2012; 19: 1060-1068.

49. Ley R, Ewings KE, Hadfield K, Cook SJ. Regulatory phosphorylation of Bim: sorting out the ERK from the JNK. Cell Death Differ 2005; 12: 1008-1014.

50. Ley R, Balmanno K, Hadfield K, Weston C, Cook SJ. Activation of the ERK1/2 signaling pathway promotes phosphorylation and proteasome-dependent degradation of the BH3-only protein, Bim. J Biol Chem 2003; 278: 18811-18816.

51. Luciano F, Jacquel A, Colosetti P, Herrant M, Cagnol S, Pages G et al. Phosphorylation of Bim-EL by Erk $1 / 2$ on serine 69 promotes its degradation via the proteasome pathway and regulates its proapoptotic function. Oncogene 2003; 22: 6785-6793.

52. Hughes R, Gilley J, Kristiansen M, Ham J. The MEK-ERK pathway negatively regulates bim expression through the 3 ' UTR in sympathetic neurons. BMC Neurosci 2011: 12.

53. Romano G, Acunzo M, Garofalo M, Di Leva G, Cascione L, Zanca C et al. MiR-494 is regulated by ERK $1 / 2$ and modulates TRAIL-induced apoptosis in non-small-cell lung cancer through BIM down-regulation. Proc Natl Acad Sci USA 2012; 109: 16570-16575.

54. Irish JM, Czerwinski DK, Nolan GP, Levy R. Altered B-cell receptor signaling kinetics distinguish human follicular lymphoma. B cells from tumor-infiltrating nonmalignant $B$ cells. Blood 2006; 108: 3135-3142.

55. Jiang AM, Clark EA. Involvement of Bik, a proapoptotic member of the Bcl-2 family, in surface IgM-mediated B cell apoptosis. J Immunol 2001; 166: 6025-6033.

56. Bretz J, Garcia J, Huang X, Kang L, Zhang Y, Toellner KM et al. Noxa mediates p18(INK4C) cell-cycle control of homeostasis in B cells and plasma cell precursors. Blood 117: 2179-2188.

57. Villunger A, Michalak EM, Coultas L, Müllauer F, Böck G, Ausserlechner MJ et al. p53- and drug-induced apoptotic responses mediated by $\mathrm{BH} 3$-only proteins Puma and Noxa. Science 2003; 302: 1036-1038.

58. Oda E, Ohki R, Murasawa H, Nemoto J, Shibue T, Yamashita T et al. Noxa, a BH3-only member of the Bcl-2 family and candidate mediator of p53-induced apoptosis. Science 2000; 288: $1053-1058$.

59. Kim JY, Ahn HJ, Ryu JH, Suk K, Park JH. BH3-only protein noxa is a mediator of hypoxic cell death induced by hypoxia-inducible factor 1 alpha. J Exp Med 2004; 199: 113-123.

60. Alves NL, Derks IA, Berk E, Spijker R, van Lier RA, Eldering E. The Noxa/Mcl-1 axis regulates susceptibility to apoptosis under glucose limitation in dividing $\mathrm{T}$ cells. Immunity 2006; 24: 703-716.

61. Rodriguez R, Matsuda M, Perisic O, Bravo J, Paul A, Jones NP et al. Tyrosine residues in phospholipase $\mathrm{C}$ gamma 2 essential for the enzyme function in B-cell signaling. J Biol Chem 2001; 276: 47982-47992

62. Du H, Wolf J, Schafer B, Moldoveanu T, Chipuk JE, Kuwana T. BH3 domains other than Bim and Bid can directly activate Bax/Bak. J Biol Chem 2011; 286: 491-501.

63. Nijhawan D, Fang M, Traer E, Zhong Q, Gao W, Du F et al. Elimination of Mcl-1 is required for the initiation of apoptosis following ultraviolet irradiation. Genes Dev 2003; 17: 1475-1486.

64. Coultas L, Bouillet P, Loveland KL, Meachem S, Perlman H, Adams JM et al. Concomitant loss of proapoptotic BH3-only bcl-2 antagonists Bik and Bim arrests spermatogenesis. EMBO J 2005; 24: 3963-3973.

65. Coultas L, Bouillet P, Stanley EG, Brodnicki TC, Adams JM, Strasser A. Proapoptotic BH3only Bcl-2 family member Bik/Blk/Nbk is expressed in hemopoietic and endothelial cells but is redundant for their programmed death. Mol Cell Biol 2004; 24: 1570-1581.

66. Spender LC, O'Brien DI, Simpson D, Dutt D, Gregory CD, Allday MJ et al. TGF-beta induces apoptosis in human B cells by transcriptional regulation of BIK and BCL-X-L. Cell Death Differ 2009; 16: 593-602.

67. Letai A, Bassik MC, Walensky LD, Sorcinelli MD, Weiler S, Korsmeyer SJ. Distinct BH3 domains either sensitize or activate mitochondrial apoptosis, serving as prototype cancer therapeutics. Cancer Cell 2002; 2: 183-192.

68. Adams JM, Harris AW, Pinkert CA, Corcoran LM, Alexander WS, Cory S et al. The c-Myc oncogene driven by immunoglobulin enhancers induces lymphoid malignancy in transgenic mice. Nature 1985; 318: 533-538.

69. Happo L, Cragg MS, Phipson B, Haga JM, Jansen ES, Herold MJ et al. Maximal killing of lymphoma cells by DNA damage-inducing therapy requires not only the p53 targets Puma and Noxa, but also Bim. Blood 2010; 116: 5256-5267.

70. Michalak EM, Jansen ES, Happo L, Cragg MS, Tai L, Smyth GK et al. Puma and to a lesser extent Noxa are suppressors of Myc-induced lymphomagenesis. Cell Death Differ 2009; 16: 684-696.

\section{Supplementary Information accompanies this paper on Cell Death and Differentiation website (http://www.nature.com/cdd)}

